\title{
Sergei Vasilievich Utechin, 1921-2004
}

The extraordinary life of Sergei Vasilievich Utechin, Professor Emeritus of Russian History at the Pennsylvania State University (1969-1984), ended on 11 July 2004, when he died at the Stanford University Medical Center from complications arising from a stroke suffered on 20 May.

S. V. Utechin was born on 18 December 1921 in the village of Tenki, near Kazan'. His father became a teacher and principal after completing a theological seminary education that included Latin, Greek, and Church Slavonic. His father also had been active in the "small deeds" populist movement, in the February revolution in Tenki volost' and in delaying the Soviet takeover there until the summer of 1918. His father steadfastly refused to join the Communist Party. Sergei Vasilievich's mother was a teacher who had studied the higher women's courses at Kazan University, from which she received her diploma in 1917.

Although his parents came under increasing political pressure during the late 1920s and early $1930 \mathrm{~s}$, they were heartened by the educational reforms of the early $1930 \mathrm{~s}$. Looking back, Sergei Vasilievich credited those educational reforms, especially the return to the classics of Russian literature, for the intellectual and moral survival of his entire generation. Nevertheless, political pressure and the "disappearance" of individuals from Kazan' persuaded the Utechin family to move to Karaganda during the summer of 1934. Three years later, when Sergei Vasilievich contemplated refusal to join the Komsomol, his mother asked, "Do you want your father and me to be arrested?" He joined.

As one of the Soviet Union's secondary school otlichniki (standouts), Sergei Vasilievich was able to enter the history faculty of Moscow State University in 1939 after an interview, not the oral examination required of less accomplished students. There he studied Russian history under K. V. Bazilevich (a student of S. V. Bakhrushin, who had studied under V. O. Kliuchevskii). Over the course of his life, Utechin would apply his gift for foreign languages to amass encyclopedic knowledge of Russian and world history. But his studies were jeopardized in the summer of 1940, when he was summoned to Lubianka for an interrogation that lasted several hours. It led to a failed attempt to expel him (in absentia) from the Komsomol in 1941.

Nazi Germany's invasion of the Soviet Union did interrupt his studies and sent him south, where he, nevertheless, came under Romanian occupation in Anapa. On 31 August 1942, Sergei Vasilievich was accused of being the Russian soldier who was responsible for killing a Romanian soldier (in fact, his poor eyesight caused him to be rejected for military service three times). He avoided execution when another Russian confirmed that he was a teacher, not a soldier. Two days later he was confronted by, but escaped from, two drunken German soldiers, one of whom suspected him of being a Jew who needed to be killed. But in November 1943, Sergei Vasilievich was captured by the Nazis, transported to a camp in Germany, and forced to labor at the Krupp shipyards while surviving on meager rations designed to cause gradual starvation.

At war's end, Sergei Vasilievich heard rumors that repatriated Russians were being imprisoned in Siberia, which prompted him to hide in a Polish camp. Then he settled in Kiel, resumed his studies, and received a doctorate of philosophy from Kiel University in 1949. During that same year, Utechin sought positions in Kiel and Berlin before receiving a scholarship to Oxford University, where he arrived in February 1950. But he soon returned to Berlin for a few months, during which time he became acquainted with Michael Josselson and Melvin Lasky. That summer he delivered a report about the prospects for freedom in the Soviet Union to the founding session of the Congress for Cultural Freedom.

At Oxford, Sergei Vasilievich became a friend (and informal student) of Sir Isaiah Berlin, but declined his formal invitation to spend a year reading analytic philosophy. Nevertheless it was precisely Berlin's philosophy of liberty and tragedy, as well as his critique of utopianism, that profoundly influenced Sergei Vasilievich's views and works for the rest of his life. 
From 1953 to 1958 Utechin worked for the BBC's foreign broadcast service while laboring on what would become Everyman's Concise Encyclopaedia of Russia (London, 1961). From 1958 to 1962 , at the invitation of Leonard Schapiro, he lectured at the London School of Economics. In 1963, Utechin's translation (in collaboration with his wife, Patricia) of Vladimir Lenin's What Is To Be Done? (Oxford, 1963) was published. More significantly, 1963 also saw the publication of Sergei Vasilievich's most influential book, Russian Political Thought: A Concise History (Dent, 1963).

In 1965, Utechin moved to Scotland, where he became an editor of the University of Glasgow's journal, Soviet Studies. Between 1965 and 1969 he lectured at many institutions, including the University of Kansas and Indiana University, before accepting a faculty appointment at the Pennsylvania State University.

Until his retirement in 1984, Sergei Vasilievich's erudition and enthusiasm caused numerous unsuspecting and casual students of history at Penn State to be "bitten by the bug" of scholarship and Russian history. Consequently, such students usually found themselves "enrolled" permanently in his ongoing graduate seminar/salon, normally conducted at his home. Sergei Vasilievich was extremely demanding when it came to historical methods. As his friend and colleague, George Enteen, observed: "His course combined exacting standards as concerns the formal methods of research with a sense of the high purpose and dignity of historical investigation."

In 1984, Utechin moved to Menlo Park, California. It was from there that he devoted his last twenty years to scholarly life at Stanford, to Russian émigré politics as a member of the National Labor Organization (NTS), to visits, lectures, and television appearances in Russia after the fall of communism, to attempts to publish Isaiah Berlin's work in Russia, and to the creation of a virtual university.

Sergei Vasilievich Utechin is survived by his second wife, Marina Pavlovna, and his son from his first marriage, Nicholas Sergeevich.

WALTER C. UHLER Independent Scholar and President, Russian-American International Studies Association November 2004 